\title{
CRITICAL THINKING SKILLS OF PHYSICS EDUCATION STUDENTS THROUGH CTL-BASED FUNDAMENTAL BIOLOGY
}

\author{
Yatin Mulyono \\ yatin.mulyono@iain-palangkaraya.ac.id \\ IAIN Palangka Raya
}

\begin{abstract}
The aim of this research is to improve critical thinking skills and cognitive learning outcomes of Physics Education students after learning fundamental biology based on CTL Experimental method. Essay and scoring rubric of critical thinking skills were used to find out what happened to students in term of critical thinking skill of doing essay. The data of students' critical thinking skills were calculated to obtain the data of critical thinking skills of the whole class. There was an improvement of students' critical thinking skills from the initial condition to the First Meeting by $6.8 \%$ and from the First Meeting to the Second Meeting by $8.12 \%$. Students cognitive learning outcomes of Meeting II obtained an average value of 76.82. Improvement of students' cognitive learning outcomes from the initial conditions to the First Meeting was 10.54 and from Meeting I to Meeting II was 3.2. The objectives or target of classical learning is achieved. The results shows that CTL experimental method can improve critical thinking skills and cognitive learning outcomes of Physics Education students.
\end{abstract}

Keywords: CTL, experimental method, critical thinking

\section{INTRODUCTION}

The results of evaluation and observation shows that the learning result of Fundamental Biology in Phase II has not reached the target. The result of critical thinking skill by observing 6 indicators of (1) giving a simple explanation, (2) providing logical arguments, (3) interpreting, (4) applying principles, (5) determining alternative problem solving, and (6) making conclusion activity in $63.16 \%$. The students' cognitive learning outcomes are poor. The result of the middle semesters examination of the students of Fundamental Biology subject shows that $56.80 \%$ of 19 students got less than 70 . The outcomes of cognitive learning result shows poor mastery in Fundamental Biology concept.

Critical thinking skill is an important ability in solving various problems. Developing the critical thinking skills of learners is the main goal of education in communities around the world (Larsson, 2017: 32-42). Santrock (2010) says critical thinking includes reflective and productive thinking as well as evaluating evidence. Critical thinking is an intellectual process in concept-making, applying, analyzing, synthesizing, and evaluating information gained from experience as a basis for taking action. So critical thinking is very important to be developed to avoid mistake and hasty decisions that can not 
be accounted for. Jensen (2011) argues that intelligent thought can not only be taught, but also a General part of the essential skills needed for success in the world. The primary focus on creativity, life skills, and problem solving makes the teaching of thought become meaningful and productive for learners. The ability to think critically is one of the most indispensable skills in problem solving. Gojkov et al. (2015) the Bologna reform puts the study in a paradoxical situation that emphasizes the need for critical thinking, as the most significant teaching objective, while on the other hand, leaves little room for achieving it. Further Fell \& Lukianova (2015), investigates the perceptions of British academics about allegedly thinking critically of foreign students and writing performance had bad results. While Stupple, et al. (2017), states that critical thinking is an important focus in higher education and essential for academic achievement.

Learning to improve critical thinking skills need the right strategy, such as Contextual Teaching and Learning (CTL) with practicum method. Students can construct their knowledge through practicum experience at the time of learning and develop their critical thinking skills. The results of Kiswadi et al. (2016) suggest that the application of CTL with the practicum method can improve the thinking skills of learners. According to Deta et al. (2013) there is an interaction between learning methods, creativity, and science process skills to cognitive and affective learning achievements. The critical thinking skills of learners are important things that need to be developed and have a positive correlation to cognitive learning outcomes. Similarly, Abrami, et al. (2008) views the important development of critical thinking skills of learners in learning in America. Those description underpins the importance of critical thinking skills for physics education students, as well as the subject of learners in Fundamental Biology courses and as prospective educators.

Hamdani (2013) states that CTL is a learning strategy that emphasizes the full involvement of learners in order to be able to find the learning material and relate it to the real life, so that learners can implement it in daily life. Learners will feel the importance of learning through the process of applying competence in daily life, and they will deeply understand what they learned. CTL was done naturally, enabling a quiet and enjoyable learning process, so learners can practice directly the things they learn. Contextual learning encourages learners to understand the nature of meaning, and the benefits of learning. It allows them to be more diligent, and motivated to constantly learn. The condition could happen, when learners realize what they need to live, and how to achieve it. Spoken by Sanjaya (2009) that The Northwest Regional Education Laboratory USA identifies six basic keys of contextual learning, (1) meaningful learning, (2) application of knowledge, (3) high-level thinking, (4) curriculum developed according to standard , (5) cultural reponsive, and (6) authentic judgment.

CTL is a learning concept whereby educators bring the real world into the learning process and encourage learners to make connections between their knowledge and application in their daily lives, while learners gain knowledge and skills from the limited context, little by little, and from the process, self-constructing, as a provision to solve problems in his life as a member of society. Contextual learning is a teaching that enables learners to strengthen, extend, and apply their academic knowledge and skills in order to solve real-world problems or simulated problems. Contextual learning occurs when learners 
apply and experience what is being taught by referring to real-world issues related to their roles and responsibilities as family members, citizens, learners and the workforce.

Student's critical thinking skills need to be improved. Fundamental Biology courses should foster critical thinking skills. Based on the description, it is necessary to do a classroom action research with the theme of CTL-based learning with experimental methods to improve the critical thinking skills of the students in Physics Education Department of Islamic State Institute Palangka Raya. This research is considered important to improve the competence of educator candidates of science, both in understanding the concepts of biology and affective competence. The results of this study is expected to be a reference in learning, especially courses Fundamental Biology.

\section{RESEARCH METHODS}

The treatment uses the design shown in Figure 1.

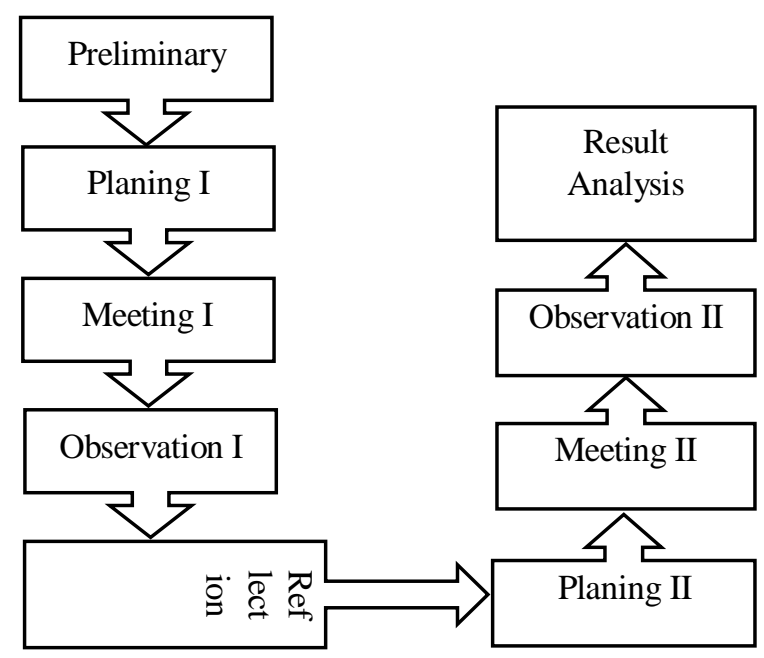

FIGURE 1. Treatment Design

Critical thinking skills data are obtained through the rubric of critical thinking skill assessment. This rubric was used in student answers when working on essays. Student answers while doing essay will show their level of critical thinking skills. Data of students' critical thinking skill is calculated, so that the data of critical thinking skill of the class is obtained. The essay question is also used to measure students' cognitive learning outcomes. 


\section{RESEARCH RESULT AND DISCUSSION}

Achievements indicators of critical thinking meetings I and II are presented in Table 1.

TABLE1. Achievements of Critical Thinking Skills Indicators

\begin{tabular}{llcc}
\hline No. & Indicators & \multicolumn{2}{c}{ Outcomes (\%) } \\
& & Meeting I & Meeting II \\
\hline 1 & Provides a simple explanation & 68,42 & 76,32 \\
2 & Give logical arguments & 64,47 & 69,74 \\
3 & Conducting interpretation & 61,84 & 72,37 \\
4 & Apply principle alternative & 56,58 & 63,16 \\
5 & Determine & 63,16 & 67,11 \\
& troubleshooting & 67,11 & 78,95 \\
\hline
\end{tabular}

Table 1 shows that the achievement of the low indicators was to apply the principle and high achievement indicator was giving simple explanation. The average achievement of the critical thinking skill meeting 1 was less than the performance indicators determined. The achievement of the cognitive domain learning outcomes Meeting I obtained from the test with the average score of cognitive learning outcomes Meeting I of 70,47 with the highest value 85.75 and the lowest 52,75. Percentage of the number of students who achieved the learning limit was $73.68 \%$ so that the cognitive learning outcomes of the Meeting did not reach the defined classical performance indicator that is $75 \%$. The achievement of the lowest indicator is to apply the principle, and the achievement of the highest indicator is to formulate the conclusion. Achievement of average indicator of critical thinking skill Meeting II has exceeded work indicator, that is equal to $71,21 \%$.

The average achievement of students' cognitive results of Meeting II was 76.82 with the highest score of 88.48 and the lowest score of 57.14. The percentage of students who have reached the learning completeness limit is $77.14 \%$. From the data it is concluded that the cognitive learning result of Meeting II has reached the classical completeness. Comparison of critical thinking skills and cognitive learning results is shown in Figure 2. 


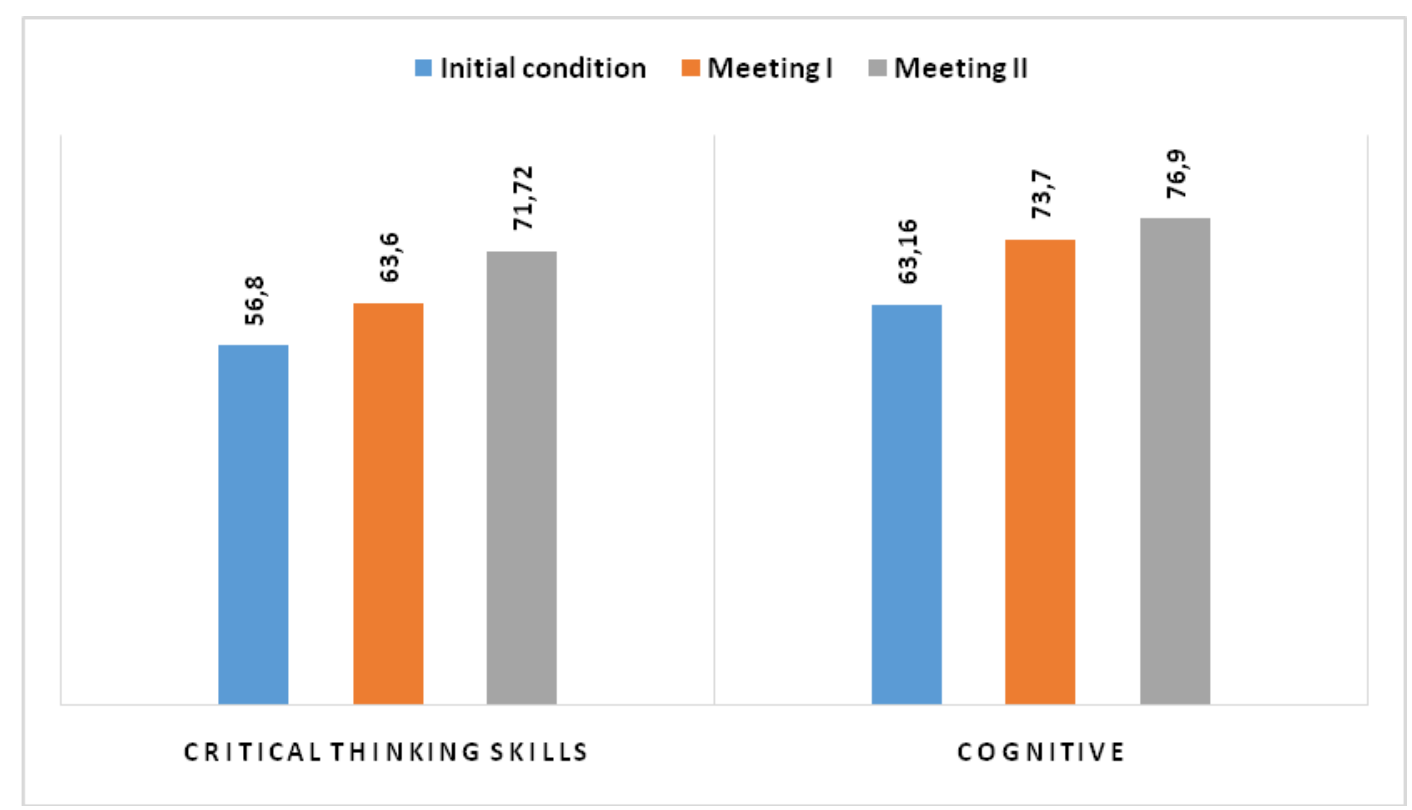

FIGURE. 2 Comparison of Critical Thinking Skills and Interfaith Cognitive Outcomes

Figure 2 shows the improvement of students' critical thinking skills from the initial condition to the first meeting was $6.8 \%$ and from the First Meeting to the Second Meeting, was $8.12 \%$. The increase of students' cognitive learning outcomes from the initial condition to the First Meeting was 10.54 and from the First Meeting to the Second Meeting was 3.2.

Second Meeting Learning was designed based on the improvement of the findings and recommendations at Meeting I. Each student observes and reads the description contained in the worksheet and then discusses it to formulate the problem and the hypothesis. The division of the group becomes smaller, enabling the increased role of the individual towards the group. Students engage in group discussions even though there are still passive students. Student coaching plays a crucial role in guiding it to construct its knowledge. The results, each group has been able to formulate questions and hypotheses well. Question formulation and hypothesis have shown relationship between independent variable and dependent variable. Curiosity, cooperation, and independence of students in the group has also been good.

The problem-solving stage of Meeting II shows that students' ability in designing experiments has increased significantly because a few days before the experimental activity, students were required to read the basic theory about the experiments they will be doing. Students have been able to formulate experimental principles, mention the variables measured, assemble tools, and make measurements. At this meeting students are already active in their group activities. The student discussion was going well. Students are already involved in assembling tools and materials and making measurements. The division of groups into smaller ones is quite effective in enabling students. With a smaller group each student had a sense responsibility to his group's activities. In addition, individual coaching can be done more intensively so as to better understand the internal condition of the students. Students were active in both experiment and discussion. Growing students 
awareness of the importance of the process during the experiment compared with the results of the experiment to be obtained.

Implementation of CTL using experimental methods can also improve students' critical thinking skills. It is consistent with the research of Syahbana (2012: 45-57) which states that there is a significant difference in the improvement of critical mathematical thinking ability between learning with CTL approach compared with conventional approach, so it is concluded that CTL approach can improve the ability of critical thinking. The CTL approach always connects the content of the material with the daily experience of the students, so they discover the meaning, and the meaning gives them a reason to learn. When students are able to interpret in their work, when they are invited to apply new material to situations that touch their lives, they will survive until they succeed.

Johnson (2010) argues that the linkage that leads to this meaning is central to the application of contextual learning. But in search of this meaning, need to pass various stages of learning process. Students need to experience gradual learning that will lead them to understand the true meaning of what they are learning. Here is the General role of a contextual approach. With appropriate model submissions, through questioning and investigating processes, students are conditioned to construct their own understanding of what they learn. Students will get used to looking for the meaning behind the problems. Then students will be guided to reflect on each part by learning section, and also reflect on the end of a learning process. This is where an actual assessment can be made, an assessment that involves the entire process of learning.

Learning General Biology-based CTL experimental methods proved to be effective in improving critical thinking skills and student cognitive outcomes. This is also in line with the results of the Salleh study, et al. (2012) which concludes that learning by simulation can have a positive impact on students' critical thinking skills. Correspondingly, Andreou etal. (2013), suggest that learning styles reflect habitual behaviors that determine different preferences in learning situations. He proved that critical thinking can develop through learning. In the study of identical learning styles found to be positively and negatively associated with critical thinking. However, the comparative findings throughout his study suggest that all learning styles may be a positive determinant of the evolution of critical thinking, suggesting that there is a relationship between learning styles and critical thinking. Similarly, Bell \& Loon (2015) research finds that simulation is an effective way for students to be actively involved in learning, bridging the gap between theory and practice. It has also been found that simulations can develop students' critical thinking skills.

Stages of CTL learning activities with experimental methods are designed to foster students' critical thinking skills. The biology concept studied is related to the context of daily life. This is in line with the opinion of Santrock (2010) which states that a way that can be done to grow students' critical thinking skills in learning is by exposing students to controversial topics or themes close to their world.

Students are stimulated to use their critical thinking potential to solve problems that occur during learning activities and problems presented through learning materials. Student's thinking skills have improved compared to previous learning activities although the increase has not been significant. The improvements made in the Second Meeting were 
able to improve the quality of learning implementation. Improving the quality of learning implementation has an impact on improving students' cognitive learning outcomes. This can be seen from the increase of cognitive learning result test result from prasiklus up to Meeting II. There are improvements made in Meeting II, especially in the case of smaller group divisions and individual assignment models have an impact on improving student affective learning outcomes. Learning patterns that link biological materials to real-world contexts can foster students' curiosity. Learning in groups with small group strategies can improve student work. Each student had a sense of responsibility and feels an important part of the group. The application of experimental methods fosters and trains the phases of concept discovery in accordance with the stages of the scientific method and the level of critical thinking skills.

Classroom organizing at the meeting $\mathrm{I}$ in a large group was less able to grow students' critical thinking skills optimally. This is because the active participation of students in the learning process was still lack. The potential of thinking of students is still less optimized. The assignment of group reporting also has not been able to maximize the students' individual thinking potential when the task of making the report was designed to be a bridge so that students are able to think in connecting the concept of biology into the real life context.

In the learning activities of Meeting II, organizing the class into small groups proved to condition of the students to maximize their potential thinking. Small groups encourage every student to participate actively in every learning activity. Assignment in making individual reports was also effective in fostering students' critical thinking skills. With improved treatment at the Second Meeting, students' critical thinking skills improved. According to Johnson (2010), CTL teaches steps that can be used in critical thinking. Contextual learning system is about intellectual achievement that comes from active participation to experience meaningful experiences.

The students' critical thinking ability is directly fit to their cognitive outcomes. This happens because students can pay attention and follow the learning process well. Students are also actively asked if there was something that is not clear during the lab activity and discussion. Students tend to be active and compact while working in groups. Students can also appreciate and actively respond positively when other groups present their work. Students' cognitive learning outcomes were increase because in experimental method CTL, lecturers explain the material that is integrated with daily life experienced by students, so that students can more easily understand and know the benefits or application of material that has been delivered. This causes students to more easily understand the material so as to obtain better cognitive learning outcomes.

The application of CTL can improve critical thinking skills and student cognitive results, because CTL facilitates full student involvement in order to discover the material learned and relate it to real life, so that students can implement it in their daily lives. Students feel the importance of learning through the process of applying competence in daily life, and they will deeply understand what they learn (Mulyono, 2018). CTL is done naturally, enabling a quiet and enjoyable learning process, so students can practice directly the things they learn. Contextual learning encourages students to understand the nature of meaning, and the benefits of learning. This allows them to be diligent, and motivated to 
constantly learn. This condition could happen, when students realize what they need to live, and how to achieve it.

CTL is a comprehensive system. CTL consists of parts that are integrated. If these parts are intertwined with one another, an effect will be more than the result of the parts given separately. The application of CTL has the following advantages: (1) CTL emphasizes the process of student involvement to find the material, meaning the learning process is oriented directly to the experience process, (2) the learning process in the context of CTL does not expect the students to receive only the lessons, and finding out for themselves the subject matter, (3) CTL encourages students to discover the relationship between the material learned and the real-world situation, meaning that students are required to capture the relationship between the learning experience in school and real life. This is very important, because by being able to correlate the material found with real life, not only for the material students found with real life, not only for the student the material will be functionally meaningful, but the material he or she studies will be embedded in the student's memory, so it will not be easy to forget, (4) CTL encourages students to apply it in life, meaning CTL not only expect students to understand the material they learn, but how the subject matter can color their behavior in daily life.

The subject matter in CTL context is not to be stacked in the box and then forgotten, but as their provision in real life.CTL is a learning system that suits the performance of the brain, to develop patterns that embody meaning, by linking academic content to the context of daily life of the students. This is important so that the information received is not only stored in short-term memory, but can be stored in long-term memory so that it will be appreciated and applied in the job task. CTL is a learning concept where educators bring the real world into the learning process and encourage students to make connections between their knowledge and application in their daily lives, while students acquire knowledge and skills from a limited context, bit by bit, and from the process, construct itself, as a provision to solve problems in his life as a member of society. Contextual learning is a teaching that enables students to strengthen, expand, and apply their academic knowledge and skills in order to solve real-world problems or simulated problems. Contextual learning occurs when students, apply and experience what is being taught by referring to real-world issues related to their roles and responsibilities as family members, citizens, students and the workforce.

Sanjaya (2009) tells about important characteristics in CTL learning process, that is; (1) CTL learning is a process of activating knowledge, what will be learned, thus the knowledge that will be obtained by students is intact knowledge which has related to each other, (2) learning to gain and increase knowledge new (acquiring knowledge). The new knowledge is derived deductively, learning begins with studying in its entirety, then paying attention to details, (3) understanding knowledge, that knowledge is acquired not to be memorized but to be understood and believed, for example by requesting a response from (4) practicing knowledge and experience (applying knowledge), that the knowledge and experience gained should be applicable in student life, so that the student behavior changes, (5) reflecting (reflecting knowledge) on the development strategy knowledge. This is done as feedback for process improvement and strategy improvement. 
Submission of material needs to be considered in order to be fun, easy to understand, not scary. Therefore the material should be chosen and adapted to the environment related to daily life (contextual) and the cognitive level of the students. Effective guidance in learning can foster students' critical thinking skills. This is in accordance with Vong and Kaewurai (2017: 85-94) that proper Instruction will be very successful in encouraging the critical thinking of learners. Any instructional instruction or environment that actively involves learners in inquiry the information and the application of knowledge will improve their critical thinking skills. lecturers need to give clear instructions and engage in interesting activities in the classroom because it affects the thinking process of the students. Lecturers should also emphasize giving students a challenging task that requires them to think critically instead of focusing on rote learning (Rodzalan \& Saat, 2015: 725-732).

Learning biology can help students think and help students held accountable for their thinking. The trained student has the belief that if he solves the problem then the truth of his problem solving is true, not because his teacher / lecturer says, but his reasoning clearly justifies it. Reasoning is a habit of brain work as well as other habits. It should be developed consistently using a variety of contexts. Knowing reasoning and proofing are General aspects. In this condition they learn to think critically of what they receive.

\section{CONCLUSION}

The conclusion of this research is that learning of Fundamental Biology with CTL model through experimental method can improve critical thinking skill of Physics Education Study Program of Islamic State Institute Palangka Raya. This learning can also improve and achieve the completeness of cognitive learning outcomes. The results of the study can be used as an alternative learning process, as well as a reference for the next research of the same kind and is expected to provide benefits and contributions to the world of education and the development of science. Preferably before applying learning with CTL model through Experimental method, lecturer / teacher gives understanding to the student about the activities that will be done especially if CTL model through experimental method if first applied. Thus, in the implementation of learning activities, students / learners no longer adapt to the model. 


\section{REFERENCES}

Abrami, P., Bernad R., Borokhovski, E. (2008). "Instructional Interventions Affecting Critical Thinking Skills and Dispositions: A Stage 1 Meta-Analysis."Educational Research,78(4): 1102-1134.

Andreou, C., Papastavrou, E., \& Merkouris, A. (2014). "Learning Styles and Critical Thinking Relationship In Baccalaureate Nursing Education: A Systematic Review.” Nurse Education Today, 34(3): 362-371.

Bell, R., \& Loon, M. (2015). "The Impact of Critical Thinking Disposition on Learning Using Business Simulations." The International Journal of Management Education, 13(2): 119-127.

Deta, U., Suparmi.,\& Wdha, S. (2013). "Pengaruh Metode Inkuiri Terbimbing dan Proyek, Kreativitas, Serta Keterampilan Proses Sains Terhadap Prestasi Belajar Siswa.”Jurnal Pendidikan Fisika Indonesia, 9: 28-34.

Fell, E. V., \& Lukianova, N. A. (2015). "British Universities: International Students' Alleged Lack of Critical Thinking." Procedia-Social and Behavioral Sciences, 215: 28.

Gojkov, G., Stojanović, A., \& Rajić, A. G. (2015). "Critical thinking of students-indicator of quality in higher education." Procedia-Social and Behavioral Sciences, 191: 591596.

Hamdani, "Strategi Belajar Mengajar”. (CV Pustaka Setia, Bandung, 2013).

Jensen, J. L. \& Lawson, A. (2011). "Effects of collaborative group composition and inquiry instruction on reasoning gains and achievement in undergraduate biology."Life Sciences Education, 10(1): 11-20.

Johnson, E.B, Contextual Teaching \& Learning: Menjadikan Kegiatan Belajar-Mengajar Mengasyikkan dan Bermakna. (Kaifa, Bandung,2010).

Kiswadi, K., Sunarno, W., \& Soeparmi, S. (2016). "Pembelajaran Fisika Berbasis Contextual Teaching and Learning Dengan Metode Eksperimen Untuk Meningkatkan Kreativitas dan Keterampilan Berpikir Kritis Siswa." Inkuiri, 5(3): 133-143.

Larsson, K. (2017). "Understanding and Teaching Critical Thinking a New Approach.'International Journal of Educational Research, 84(1): 32-42.

Mulyasa, E. Menjadi Guru Profesional: Menciptakan Pembelajaran Kreatif dan Menyenangkan. (Remaja Rosdakarya, Bandung, 2006).

Mulyono, M. (2018). Improving Creativity of the Future Physics Teachers Through Fundamental Biology Learning Based on CTL with Experimental Method. Indonesian Journal of Science and Education, 2(1): 62-68

Rodzalan, S. A., \& Saat, M. M. (2015). "The Perception of Critical Thinking and Problem Solving Skill Among Malaysian Undergraduate Students". Procedia-Social and Behavioral Sciences, 172, 725-732.

Salleh, S.M., Tasir,Z. \& Shukor, N.A. (2012). Web-Based Simulation Learning Framework to Enhance Students' Critical Thinking Skills. Procedia - Social and Behavioral Sciences.International Educational Technology Conference (IETC) 2012, 64, 372 381. 
Sanjaya, W. "Strategi Pembelajaran Berorientasi Standar Proses Pendidikan."(Prenada, Jakarta, 2009).

Santrock, J. W. Psikologi Pendidikan, edited by Wibowo,T. (Kencana, Jakarta,2010).

Stupple, E. J., Maratos, F. A., Elander, J., Hunt, T. E., Cheung, K. Y., \& Aubeeluck, A. V. (2017). Development of the Critical Thinking Toolkit (CriTT): A measure of student attitudes and beliefs about critical thinking. Thinking Skills and Creativity, 23: 91100.

Syahbana, A. (2012). "Peningkatan Kemampuan Berpikir Kritis Matematis Siswa SMP Melalui Pendekatan Contextual Teaching and Learning". EDUMATICA| Journal Pendidikan Matematika,2(01): 45-57.

Vong, S. A. \& Wareerat Kaewurai, W. (2017). Instructional Model Development to Enhance Critical Thinking and Critical Thinking Teaching Ability of Trainee Students at Regional Teaching Training Center in Takeo Province, Cambodia. Kasetsart Journal of Social Sciences, 38(1), 88-95. 
